\section{Antioxidant and antimicrobial activity of cathode and anode water in Coffea arabica L. seeds}

\author{
Ana Luiza Oliveira Vilela ${ }^{1}$ iD , Sttela Dellyzete Veiga Franco da Rosa ${ }^{2 *}$ (D), Stefânia \\ Vilas Boas Coelho ${ }^{1}$ iD, Nathália Aparecida Bragança Fávaris ${ }^{1}$ iD, Tatiana Botelho \\ Fantazzini $^{1}$ (D) , Júlia Lima Baute ${ }^{1}$
}

ABSTRACT: Seed deterioration induces the formation of free radicals and proliferation of microorganisms, but the application of external antioxidants may lessen these effects. The aim of this study was to investigate the antioxidant and antimicrobial activity of cathode and anode water on the physiological quality and health of Coffea arabica L. seeds. Part of the seeds were soaked in cathode water and the other part in anode water for periods of $1,6,12,24$, and 36 hours. The physiological quality of the seeds was evaluated by the germination test and tetrazolium test, and seed health by the Blotter test. Analysis of variance and Pearson correlation analysis were performed on the data for all the response variables. Soaking in cathode water or anode water up to 24 hours improves the physiological quality of coffee seeds. Anode water has a beneficial effect on the health of coffee seeds, reducing the incidence of Fusarium spp., Penicillium spp., Cladosporium spp., and Alternaria spp. after one hour of soaking and of Aspergillus spp. after six hours. Soaking in cathode water for a period of one hour leads to a reduction in the fungi Aspergillus spp., Fusarium spp., Cladosporium spp., and Alternaria spp., and reduction in Penicillium spp. after six hours.

Index terms: antioxidant activity, fungicidal activity, physiological quality, seed health, hydrolyzed water.

\section{Atividade antioxidante e antimicrobiana da água catódica e anódica em sementes de Coffea arabica L.}

RESUMO: A deterioração das sementes induz à formação de radicais livres e a proliferação de microrganismos, sendo que a aplicação de antioxidantes externos pode amenizar estes efeitos. Objetivou-se estudar a ação antioxidante e antimicrobiana da água catódica e anódica sobre a qualidade fisiológica e sanitária de sementes de Coffea arabica L. Parte das semente foi embebida em água catódica, e a outra parte em água anódica, por períodos de 1, 6, 12, 24 e 36 horas. A qualidade fisiológica das sementes foi avaliada pelo teste de germinação e de tetrazólio, e a qualidade sanitária pelo Blotter test. Os dados foram submetidos às análises e correlação de Pearson para todas as variáveis resposta avaliadas. A embebição nas águas catódica e anódica, até $\mathbf{2 4}$ horas promove melhora na qualidade fisiológica de sementes de café. A água anódica apresenta efeito benéfico à qualidade sanitária das sementes de café, reduzindo a incidência de Fusarium spp, Penicillium spp, Cladosporium spp e Alternaria spp. após uma hora de embebição e de Arspergillus spp após seis horas. A embebição em água catódica por período de uma hora proporciona redução dos fungos Arspergillus spp, Fusarium spp, Cladosporium spp e Alternaria spp, e de Penicillium spp com seis horas.

Termos para indexação: ação antioxidante, ação fungicida, qualidade fisiológica, qualidade sanitária, água hidrolisada.
Journal of Seed Science, v.43, e202143011, 2021

http://dx.doi.org/10.1590/ 2317-1545v43244602
${ }^{*}$ Corresponding author
E-mail: sttela.rosa@embrapa.br

Received: $10 / 22 / 2020$.

Accepted: 11/23/2020.

\footnotetext{
${ }^{1}$ Universidade Federal de Lavras (UFLA), Caixa Postal 3037, 37200000 - Lavras, MG, Brasil.
}

${ }^{2}$ Empresa Brasileira de Pesquisa Agropecuária (Embrapa Café) Brasília, DF, Brasil. 


\section{INTRODUCTION}

The species Coffea arabica L. is of great economic and social importance in Brazilian agriculture; it is a crop that continues to expand and is widely accessible to the population. Greater demand and consumption of coffee by Brazilians corresponds to a global growth trend. Brazil is currently the largest coffee producer worldwide (ICO, 2019); production in the 2018 crop season reached 61.66 million bags, with a planted area of approximately 1.84 million hectares (CONAB, 2019).

Coffee plant propagation is through seeds, and crop fields are established through planting of seedlings. Healthy seeds of high physiological quality are essential to obtain high vigor seedlings.

The germination capacity of coffee seeds declines after six months of storage and, thus, seedling production is concentrated in certain periods of the year, which might not be the most appropriate for planting. This hinders the formation and maintenance of safety stocks of seeds and their use in the medium to long term.

Various studies have shown that seed deterioration is induced by the formation of free radicals, enzymatic degradation, inactivation or reduction in respiratory activity, and loss of cell membrane activity (Vidigal et al., 2009; Sharma et al., 2012; Marcos-Filho, 2015; Coelho et al., 2017; Abreu et al., 2018). Nevertheless, the negative effect of reactive oxygen species (ROSs) can be reduced by defense mechanisms. The application of external antioxidants is an alternative for lowering the production of ROSs, with a direct effect, or for improving the endogenous antioxidant activity of the seeds (Berjak et al., 2011).

In this respect, cathode water generated by electrolysis of a solution containing calcium chloride and magnesium chloride has had antioxidant effects, reducing the number of free radicals (Hanaoka, 2001; Hanaoka et al., 2004; Hiraoka et al., 2004). Cathode water (reduced solution from hydrolysis) has high pH (9.0-10.0), with a large amount of dissolved active hydrogen, whereas anode water (oxidized solution), with acid $\mathrm{pH}$, has a large amount of dissolved oxygen and may perform a decontamination function, with antimicrobial activity (Hanaoka et al., 2004).

Thus, cathode water and anode water can lead to improvement in deteriorated seeds by reduction of oxidative damage and cell degradation and by antifungal activity (Berjak et al., 2011; Naidoo et al., 2016). Their use constitutes a simple and non-toxic method of seed improvement (Pammenter and Berjak, 2014). Thus, the aim of this study was to analyze the antioxidant and antimicrobial activity of cathode water and anode water on the physiological quality and health of Coffea arabica L. seeds, investigating the best exposure time of seeds to these solutions.

\section{MATERIAL AND METHODS}

The experiment was conducted in the Central Seed Laboratory and the Seed Pathology Laboratory of the Departments of Agriculture and of Plant Pathology of the Universidade Federal de Lavras (UFLA). We used seeds of Coffea arabica L., cultivar Catuaí amarelo IAC 62, from the 2017/2018 crop season, harvested from the Fundação Procafé coffee field in the municipality of Varginha, MG, Brazil, at geographic coordinates $21^{\circ} 34^{\prime} 00^{\prime \prime} \mathrm{S}$ and $45^{\circ} 24^{\prime} 22^{\prime \prime}$ W, with altitude of 1000 $\mathrm{m}$. Climate in the region is humid mesothermal, with mean temperatures of $16{ }^{\circ} \mathrm{C}$ in the winter period and $23.1{ }^{\circ} \mathrm{C}$ in the summer period, according to the Köppen classification. Mean annual rainfall is $1400 \mathrm{~mm}$.

The fruit was manually harvested in the cherry maturation stage and then washed for elimination of hollow shell, malformed, and bored fruit and of impurities. The fruit was pulped and seeds were semi-washed by fermentation in water for 24 hours, and then kept on a drying screen in the shade until reaching $12 \%$ moisture content. After that step, these seeds, which exhibited $98 \%$ germination, were placed in plastic bags and then in cold storage at $10{ }^{\circ} \mathrm{C}$ and $55 \%$ relative humidity for a period of fifteen months to obtain seeds with reduced health and physiological quality to carry out the experiment.

After the seeds remained in storage for fifteen months, their profile was determined through moisture content by the laboratory oven method at $105^{\circ} \mathrm{C}$ for 24 hours (Brasil, 2009), through physiological quality by the germination test 
(Brasil, 2009), and through embryo viability by the tetrazolium test (Clemente et al., 2011). The seeds that constituted the control treatment had $12 \%$ moisture content, $64 \%$ normal seedlings, and $94 \%$ viable embryos. These seeds were then soaked in cathode water or in anode water in "gerbox" (germination box) plastic boxes and kept at a temperature of $30^{\circ} \mathrm{C}$ under light for periods of $1,6,12,24$, and 36 hours. The cathode water and the anode water were produced according to the methodology described by Berjak et al. (2011), with modifications: $1 \mathrm{~L}$ of solution containing 0.5 $\mathrm{mM} \mathrm{CaCl} 2 \cdot 2 \mathrm{H}_{2} \mathrm{O}$ and $0.5 \mathrm{mM} \mathrm{MgCl} \cdot 6 \mathrm{H}_{2} \mathrm{O}$ as electrolytes was divided and placed in a horizontal tub designed for electrophoretic run. The circuit was completed using a agar-based salt bridge containing potassium chloride, and the solution was electrolyzed applying a $60-\mathrm{V}$ potential difference. Electrolysis was performed for one hour at ambient temperature, producing $500 \mathrm{~mL}$ of anode water (oxidized fraction) with $\mathrm{pH}$ near $3-4$, and $500 \mathrm{~mL}$ of cathode water (reduced fraction) with $\mathrm{pH}$ near 11-12, which were used to soak the seeds and obtain the treatments to be tested. After the soaking periods, the seeds were evaluated for physiological quality and seed health.

\section{Evaluation of seed physiological quality}

The germination test was performed on the seeds soaked in cathode water or anode water for different periods in order to evaluate their physiological quality. Four replications of 50 seeds were used, sown on two sheets of "germitest" (germination testing) paper moistened with distilled water in the amount of 2.5 times the weight of the dry paper and covered by one more sheet of germination paper. Seeds were sown with the aid of an acrylic sheet for the purpose of placing the seeds at equal distance from each other. After that, the seeds and papers were rolled and these rolls were kept in a seed germinator at a constant temperature of $30^{\circ} \mathrm{C}$ under light for 30 days (Brasil, 2009). Along with evaluation of normal seedlings at 30 days in the germination test, the vigor of the seeds under the treatments was evaluated by means of root emergence (\%) at 15 days, seedlings with expanded cotyledonary leaves (\%), and seedling dry matter at 45 days after sowing, as well as strong normal seedlings (\%) at 30 days, considering the seedlings with root-hypocotyl axis greater than or equal to $3 \mathrm{~cm}$ (Coelho et al., 2017).

For determination of dry matter of normal seedlings, the shoots were separated from the roots using a scalpel, and both parts were placed in paper bags and kept in an air-circulation laboratory oven at $60{ }^{\circ} \mathrm{C}$ until reaching constant weight, which occurred at five days, and the results were expressed in mg.seedling ${ }^{-1}$ (Coelho et al., 2017). These results were also used as an indication of coffee seed vigor.

For the tetrazolium test, four replications of 25 seeds of each treatment in cathode water or anode water were used, which were soaked in distilled water for 36 hours for embryo extraction. After extraction, the embryos were kept in polyvinylpyrrolidone (PVP) antioxidant solution and then washed in running water and immersed in $0.5 \%$ tetrazolium solution in dark bottles at a temperature of $30^{\circ} \mathrm{C}$ for three hours (Clemente et al., 2011). After that, the embryos were evaluated with the aid of a stereoscopic magnifying glass with 10X magnification for visualization of internal and external aspects after longitudinal sectioning. The results were expressed in percentage of viable embryos (Brasil, 2009).

\section{Seed health evaluation}

Eight replications of 25 seeds were used for the seed health test for each treatment of soaking in cathode water or anode water; the seeds were distributed in $15-\mathrm{cm}$ diameter Petri dishes on a sheet of filter paper moistened with distilled water and water-agar (1:1 proportion) medium, both sterilized. The seeds were kept for seven days at $20^{\circ} \mathrm{C} \pm 2$ in an incubation chamber with 12 -h photoperiod. The incidence of fungi on the seeds was evaluated with a stereoscopic microscope through the morphological traits of their structures. The results were expressed in percentage of contaminated seeds.

\section{Experimental design and statistical analysis}

A completely randomized experimental design was used, and the data of physiological evaluation were obtained in a 2 (types of water) $\times 5$ (soaking periods) factorial arrangement, with four replications. Mean values were compared 
by Tukey's test and Student's t-test $(\alpha=0.05)$, and the quantitative data by regression analysis. The SISVAR statistical program was used for statistical analysis (Ferreira, 2014).

The results of seed health were analyzed separately for each type of water, anode or cathode, in the different seed soaking times and compared to the control. The non-parametric Kruskal-Wallis test was used on the data, and the mean values were compared by the Bonferroni test using the $\mathrm{R}$ software ( $\mathrm{R}$ Development Core Team, 2018).

The Pearson correlation coefficient was calculated to evaluate the relationship between the soaking times in water and the physiological and health results of the seeds.

\section{RESULTS AND DISCUSSION}

\section{Seed physiological evaluation}

The results of analysis of variance of the physiological evaluation showed significant interaction of the type of water (anode and cathode) and different soaking time factors for the results of seedlings with expanded cotyledonary leaves, root dry matter, and viable embryos in the tetrazolium test (Table 1 and Figure 1). The percentage of expanded cotyledonary leaves (\%) declined in relation to the control (seeds without treatment) in all the soaking times in anode water, except for the 1 hour soaking time (Table 1). In the results of seeds soaked in cathode water, the mean values did not differ significantly from the control for up to 24 hours of soaking (Table 1). For the seeds soaked for 36 hours, the percentage of expanded cotyledonary leaves was lower than the control, indicating loss of vigor, evaluated by the percentage of seedlings with expanded cotyledonary leaves for this time of soaking in cathode water.

The 12-hour soaking time in cathode water led to the highest percentage of seedlings with expanded cotyledonary leaves (Figure 1). However, after twelve hours, this percentage declined as soaking time in cathode water increased. In addition, the 36-hour soaking time hurts the seeds in both cathode water and anode water (Figure 1), with reduction in performance for the variables analyzed, except for viable embryos.

The results of root dry matter of seedlings coming from soaked seeds exhibited a decline in physiological quality with increase in soaking beginning at 12 hours (Table 1 and Figure 1, B). For cathode water, there was an increase in root dry matter of the seedlings when the seeds were soaked for six or twelve hours, indicating improvement in the quality of these seeds (Figure 1, B). After that time, there was reduction in the vigor of these seeds compared to the other treatments.

The results of embryo viability in the tetrazolium test (Table 1) showed that, in general, soaking in cathode water led to higher percentages than soaking in anode water. Compared to the control, there was no significant difference

Table 1. Results of evaluation of the physiological quality of coffee seeds soaked in cathode and anode water for different times.

\begin{tabular}{|c|c|c|c|c|c|c|}
\hline \multirow{2}{*}{ Time (hours) } & \multicolumn{2}{|c|}{$\begin{array}{c}\text { Expanded cotyledonary leaves } \\
(\%)\end{array}$} & \multicolumn{2}{|c|}{ Root dry matter (mg.seedling ${ }^{-1}$ ) } & \multicolumn{2}{|c|}{$\begin{array}{c}\text { Viable embryos in tetrazolium } \\
(\%)\end{array}$} \\
\hline & Anode & Cathode & Anode & Cathode & Anode & Cathode \\
\hline 1 & $50 \mathrm{aA}$ & $47 \mathrm{aA}$ & $8.28 \mathrm{aB}$ & $6.73 \mathrm{bB}$ & $81 \mathrm{bA}$ & 91 aA \\
\hline 6 & $49 \mathrm{aB}$ & 51 aA & $8.76 \mathrm{aA}$ & $8.80 \mathrm{aA}$ & 76 bB & $90 \mathrm{aA}$ \\
\hline 12 & $43 \mathrm{aB}$ & 56 aA & $6.85 \mathrm{bB}$ & $8.95 \mathrm{aA}$ & 79 bB & $94 \mathrm{aA}$ \\
\hline 24 & $40 \mathrm{aB}$ & 51 aA & $6.85 \mathrm{aB}$ & $7.50 \mathrm{aB}$ & $91 \mathrm{aA}$ & 82 bB \\
\hline 36 & $40 \mathrm{aB}$ & $19 \mathrm{bB}$ & $7.83 \mathrm{aB}$ & $7.40 \mathrm{aB}$ & 77 bB & $92 \mathrm{aA}$ \\
\hline Control & \multicolumn{2}{|c|}{$72 \mathrm{~A}$} & \multicolumn{2}{|c|}{$6.07 \mathrm{~B}$} & \multicolumn{2}{|c|}{$94 \mathrm{~A}$} \\
\hline
\end{tabular}



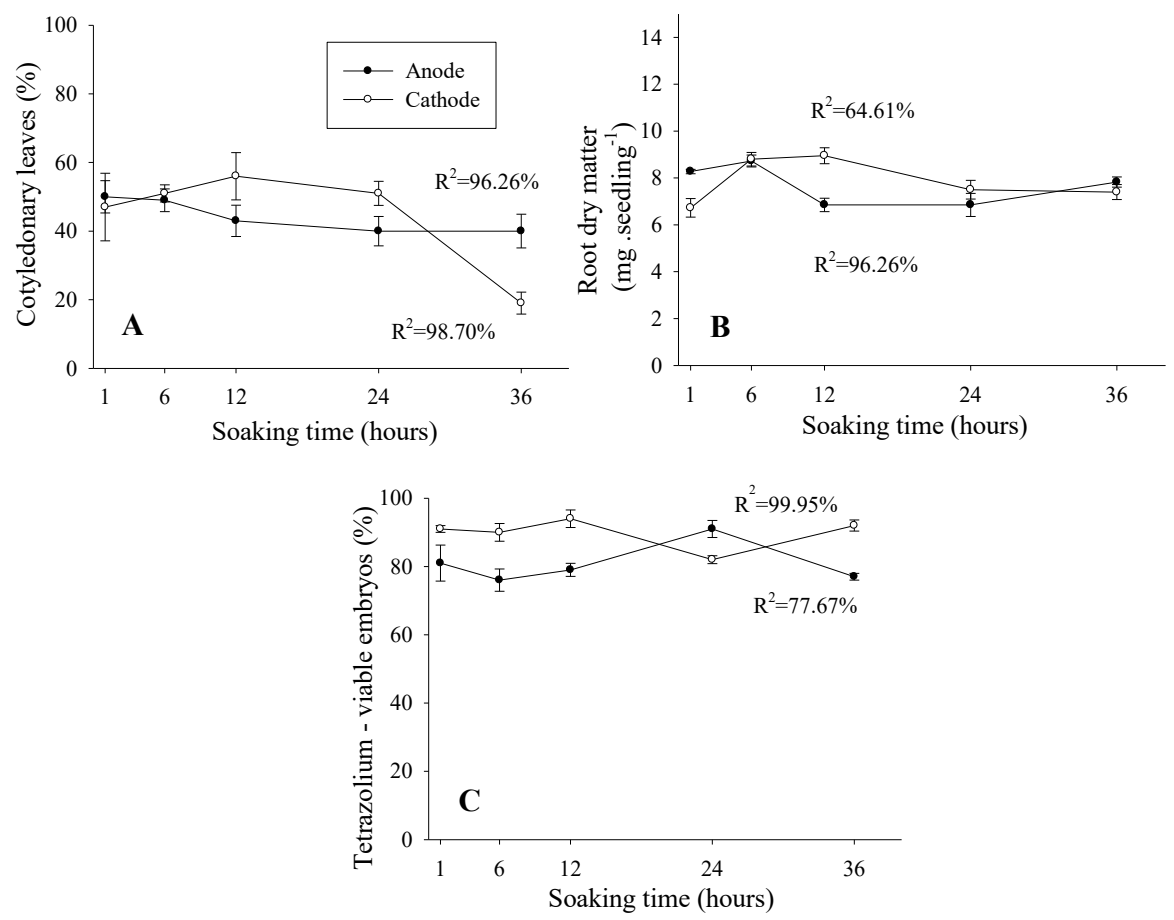

Figure 1. Physiological quality of Coffea arabica L. seed soaked in anode water and cathode water for different times. (A) Seedlings with expanded cotyledonary leaves (\%); (B) Root dry matter (mg.seedling ${ }^{-1}$ ); (C) Viability of embryos by the tetrazolium test (\%).

due to soaking in anode water for the times of 1 hour and 24 hours, but the values of embryo viability were lower at the times of 6,12 , and 36 hours of soaking (Table 1). Soaking in cathode water resulted in viability in tetrazolium statistically equal to the control, except for the time of 24 hours. In anode water with 24 hours of soaking (Figure $1, \mathrm{C}$ ), there was an increase in the percentage of viable embryos and decline with 36 hours, whereas in cathode water, there was an increase in the percentage of viable embryos up to 12 hours. In general, the percentage of viable embryos was less affected by soaking of seeds in cathode or anode water.

According to the results of analysis of variance of the germination data, there was no significant interaction of the soaking type and soaking time factors in the hydrolyzed water. Nevertheless, there was a significant effect of soaking time separately. Germination increased up to the soaking time of 24 hours (Figure 2), indicating improvement in the physiological quality of the coffee seeds when soaked, but quality decreased with 36 hours.

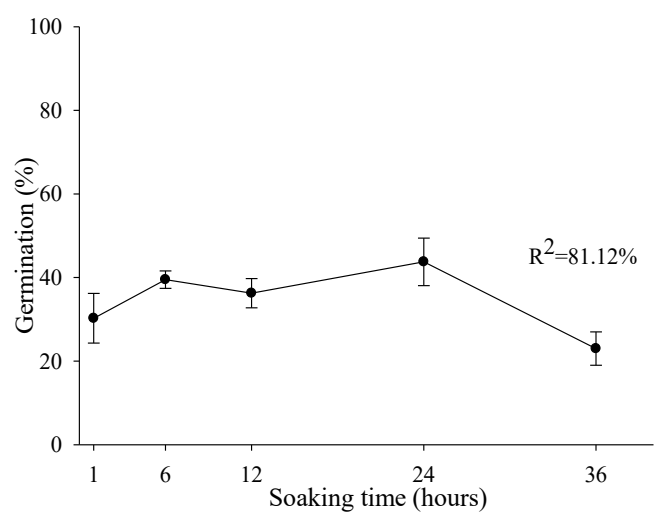

Figure 2. Normal seedlings from Coffea arabica L. seeds soaked in cathode water or anode water for different times. 
Table 2. Results of strong normal seedlings and shoot dry matter (mg.seedling $\left.{ }^{-1}\right)$ in Coffea arabica L. seeds soaked in anode water or cathode water.

\begin{tabular}{ccc}
\hline Water & Strong normal seedlings (\%) & Shoot dry matter (mg.seedling ${ }^{-1}$ ) \\
\hline Anode & $17 \mathrm{aA}$ & $51.23 \mathrm{bA}$ \\
Cathode & $6 \mathrm{bB}$ & $55.30 \mathrm{aA}$ \\
\hline Control & $15 \mathrm{~A}$ & $50.92 \mathrm{~A}$ \\
\hline
\end{tabular}

*Mean values followed by the same lowercase letter in the column do not differ statistically from each other by Tukey's test at $5 \%$ probability and mean values followed by the same uppercase letter do not differ from the control by the T test.

The results of percentage of strong normal seedlings and shoot dry matter did not show significant differences according to soaking times, but there was an effect of the type of water (Table 2). The anode water led to higher percentages of strong normal seedlings compared to the results of cathode water. The control did not differ statistically from the treatment with anode water. However, there was a lower percentage of strong normal seedlings in the seeds soaked in cathode water compared to the control (Table 2).

At 45 days after the beginning of the germination test, shoot dry matter of the seedlings was also evaluated (Table 2). An effect from the types of water was found; the seeds under the cathode water treatment had significantly superior results compared to the treatment with immersion in anode water, while soaking of the seeds in anode and cathode water did not differ statistically from the control (without soaking) (Table 2).

In studies on the effect of cathode water in in vitro systems, antioxidant effects were found by the high capacity of this water to connect to reactive oxygen species (Hanaoka, 2001; Hanaoka et al., 2004; Hiraoka et al., 2004; Franceschelli et al., 2016). However, this effect, up to then, had not been widely tested in seeds. Berjak et al. (2011) obtained good results in embryonic axes of a recalcitrant tree species, and reported that the beneficial effects of cathode water were even more apparent in sprout and root production.

In the present study, considering the evaluations performed, the effect of soaking in cathode water was similar to the studies cited, since in certain soaking times there were better results than the control, as observed for root dry matter with six and twelve hours of soaking.

In addition, in the studies of Hanaoka (2001) on the chemical properties of cathode water, a significant increase was shown in the antioxidant activity of ascorbic acid in an in vitro system, actively participating in the endogenous antioxidant metabolism. Thus, according to the observations of this author (Hanaoka, 2001), cathode water has not only protective effects but also growth promoting effects in alleviating the damaging activity of reactive oxygen species, related to natural deterioration of the seeds, as well as in assistance of endogenous production of antioxidants.

Anode water, for its part, is known for its antibacterial, antiviral, and antifungal effects, and it can have cytotoxic and antimetabolic activity without attacking human cell tissue (Atanasov et al., 2014). According to Gluhchev et al. (2015), the biocidal elements of anode water are not toxic to the somatic cells of mammals and are used as decontaminants for the in vitro growing of plants (Berjak et al., 2011). In the present study, the anode water was not toxic to the lowquality coffee seeds when they were soaked for up to an hour, since the results were similar or better than those of the control (seeds without soaking).

\section{Seed health evaluation}

In evaluation of the health of coffee seeds under the cathode or anode water soaking treatments, six species of fungi were found: Aspergillus spp., Fusarium spp., Penicillium spp., Cladosporium spp., Alternaria spp., and Phoma spp., the results of which are shown in Figures 3 and 4.

The results of seed health evaluation show that seeds under soaking in anode water for various times (Figure 3) generally have a smaller incidence of fungi, with different effects from soaking. The time of one hour of soaking in anode 
water was enough to significantly reduce the incidence of the fungi Fusarium spp., Penicillium spp., Cladosporium spp., and Alternaria spp. The incidence of the fungus Aspergillus spp. decreases with six hours of soaking; however, it increases beginning at 24 hours. For Phoma spp., there was not a consistent response with the increase in time of soaking in anode water - reduction with one hour of soaking, but increases and decreases at longer times.

One hour of soaking in cathode water was also sufficient to reduce the incidence of the fungi, except for Penicillium spp., which showed reduction with six hours and Phoma spp., in which there was an increase in growth of this fungus after one hour and significant reduction from twelve hours on. Thus, the hydrolyzed water, both anode water and cathode water, were effective in inhibiting the growth of most of the fungi with only one hour of soaking (Figures 3 and 4).

Aspergillus spp.

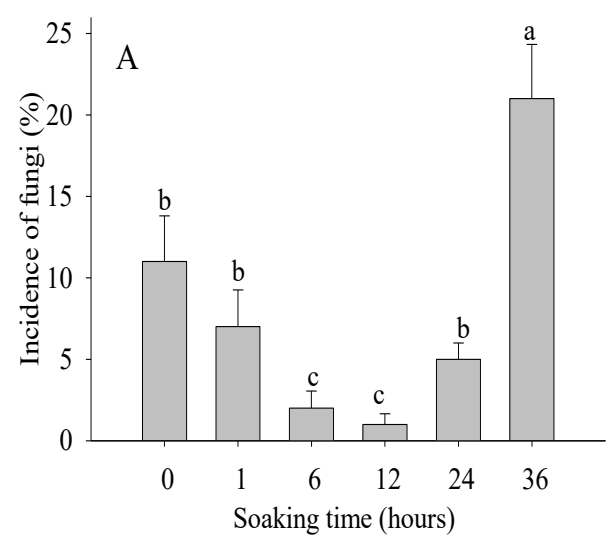

Penicillium spp.

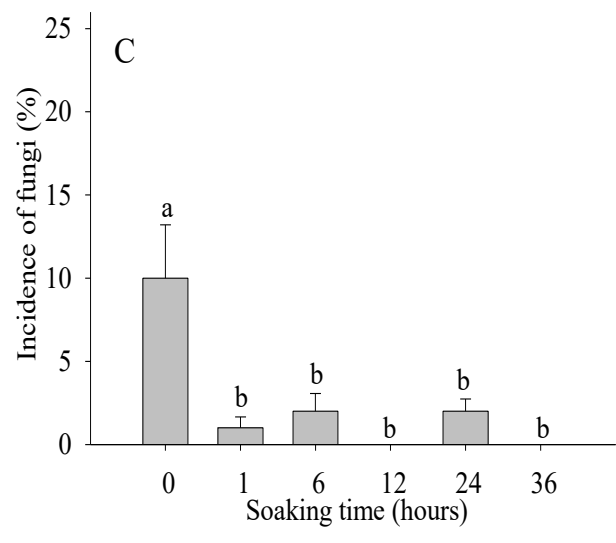

Alternaria spp.

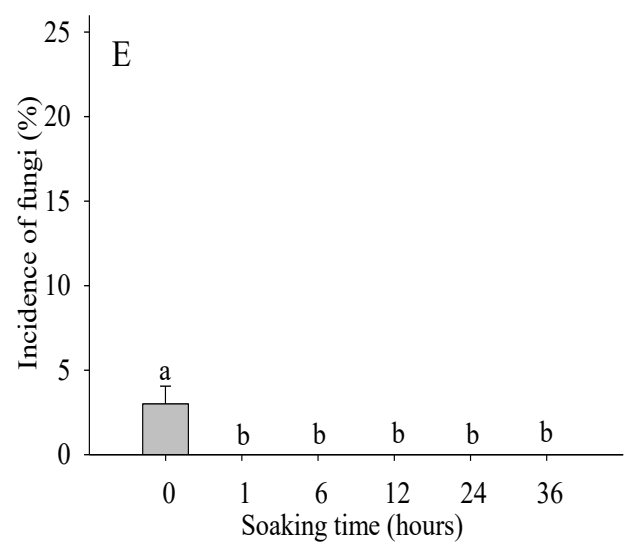

Fusarium spp.

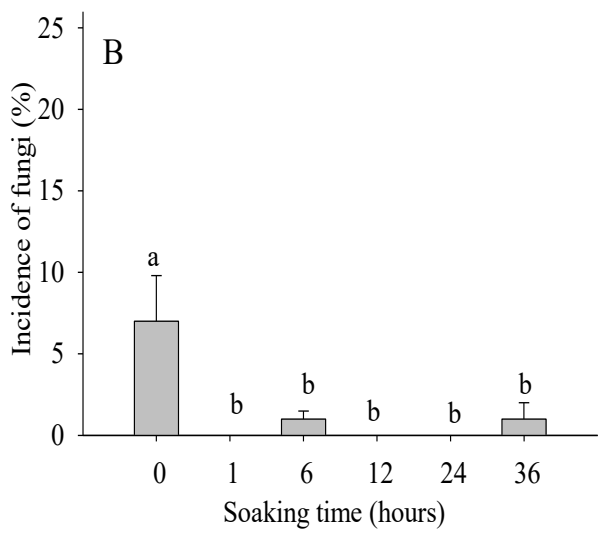

Cladosporium spp.

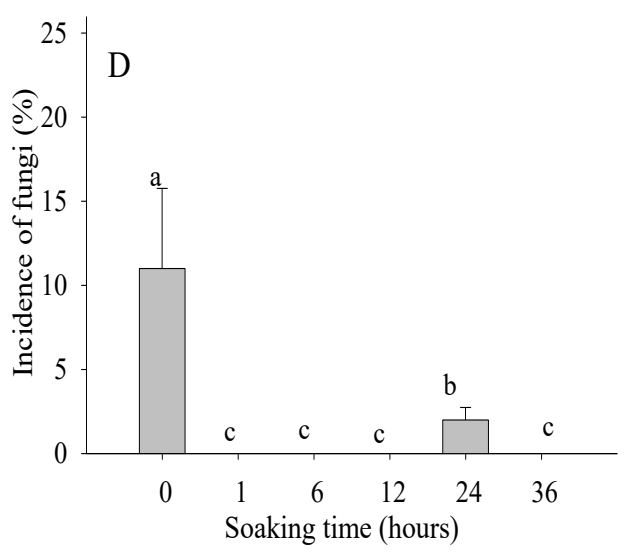

Phoma spp.

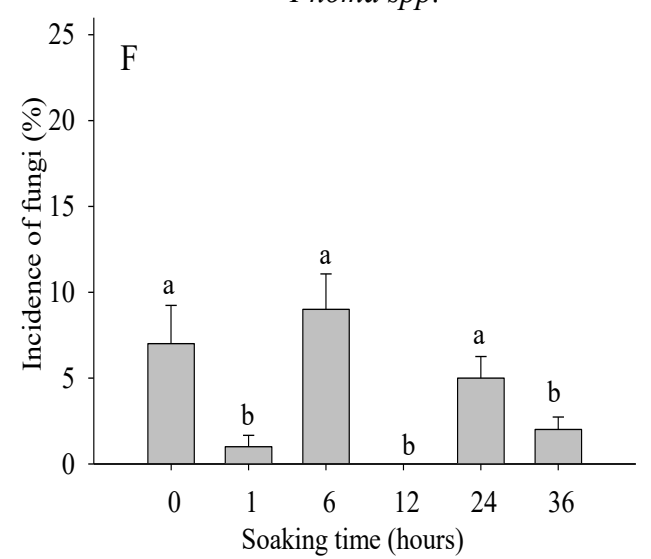

Figure 3. Incidence of fungi in Coffea arabica L. seeds after soaking in anode water for different times. 
Aspergillus spp.

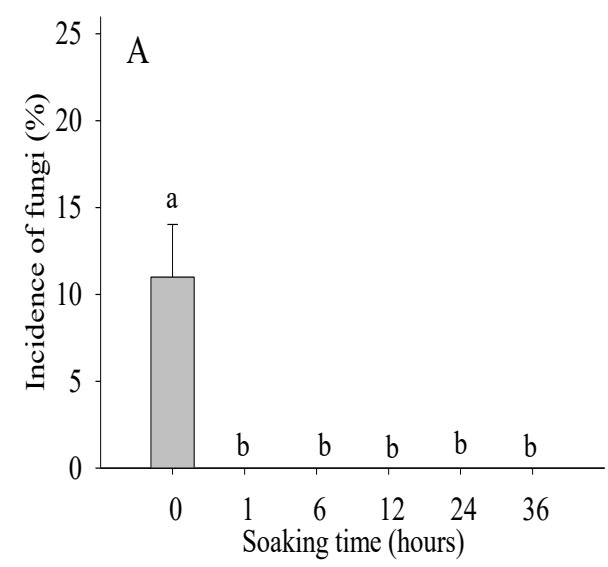

Penicillium spp.

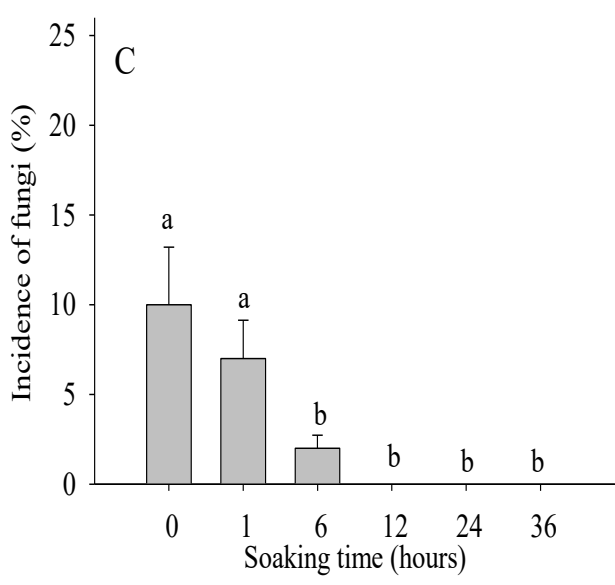

Alternaria spp.

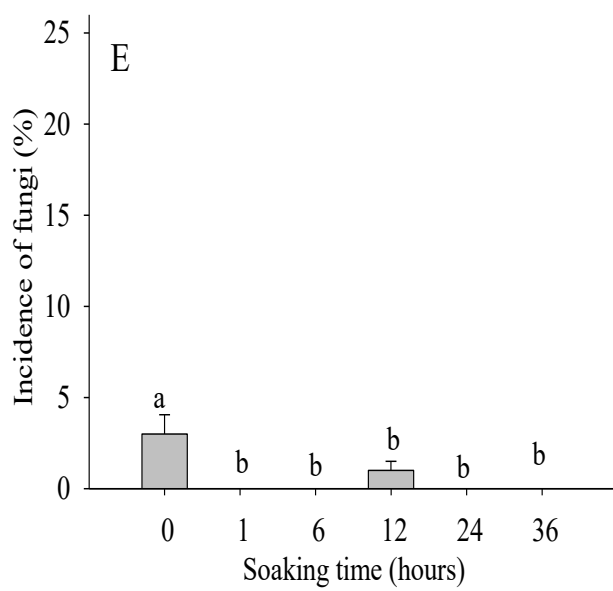

Fusarium spp.

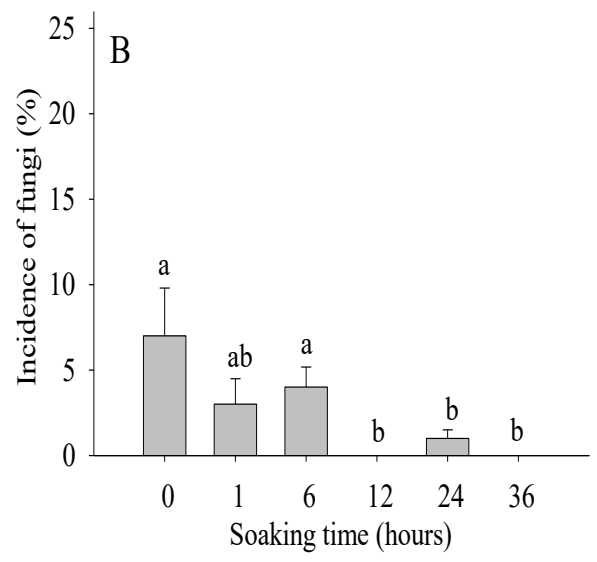

Cladosporium spp.

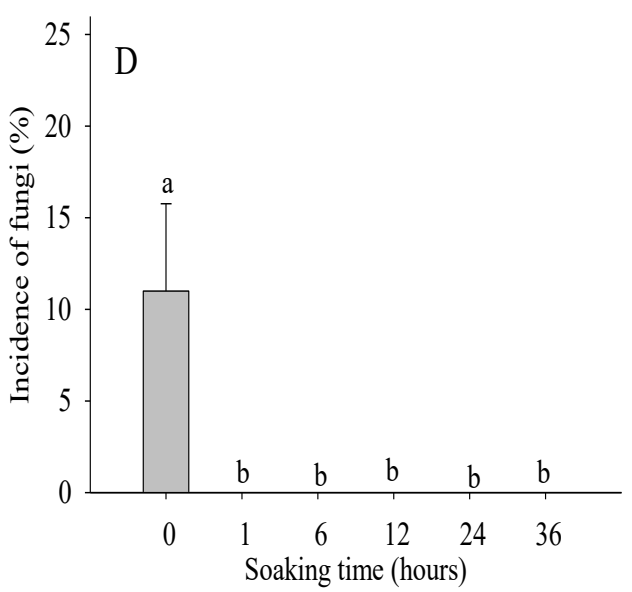

Phoma spp.

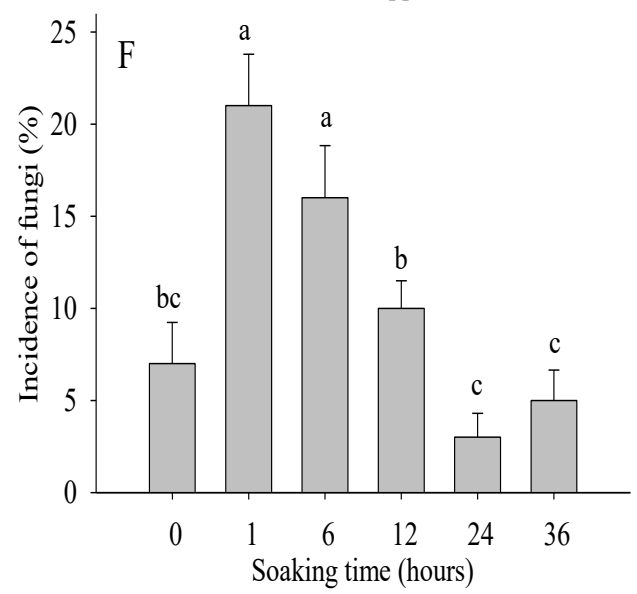

Figure 4. Incidence of fungi in Coffea arabica L. seeds after soaking in cathode water for different times.

Gluhchev et al. (2015) studied the virucidal and biocidal effect of anode and cathode water and confirmed the strong influence of the electrochemically activated types of water, cathode and anode, on a species of virus (Classical Swine Fever Virus - CSF) and a species of bacteria (Bacterium E. coli DH5). Berjak et al. (2011) studied the antioxidant effect of anode and cathode water on embryonic axes of recalcitrant species after cryopreservation and only observed 
positive results after the addition of a treatment with neomycin sulfate for two minutes. Nevertheless, in the present study, without the addition of complementary antifungal agents, with soaking in anode water or cathode water, there were few or no fungi at one and six hours.

Figures 5 and 6 represent the Pearson correlation coefficients between the soaking times and the response variables, i.e., physiological quality (A) or incidence of fungi (B). This coefficient, which measures the degree of correlation between two quantitative variables is a dimensionless index with values from -1.0 to 1.0, which reflects the intensity of a linear relationship between two datasets. In the present study, the Pearson correlation coefficients was used to measure the relationship between the treatment with the hydrolyzed water and the incidence of the fungi, and the relationship between the treatment with hydrolyzed water and seed physiological quality. There was high negative correlation between the soaking times and the percentage of seedlings with expanded cotyledonary leaves, both in anode water and in cathode water (Figures $5 \mathrm{~A}$ and $6 \mathrm{~A}$ ), with indices of -0.71 and -0.79 , respectively, indicating reduction in seed vigor with an increase in soaking time. In anode water, there was also reduction in the percentage of normal seedlings, with an index of -0.66 . This may have occurred as a result of probable phytotoxicity caused by hydrolyzed water to the seeds due to prolongation of the exposure at the higher soaking times. According to the root emergence and strong normal seedling variables, a positive correlation was observed, i.e., the longer the exposure time of the seeds to the anode water, the greater the mean values of these variables.

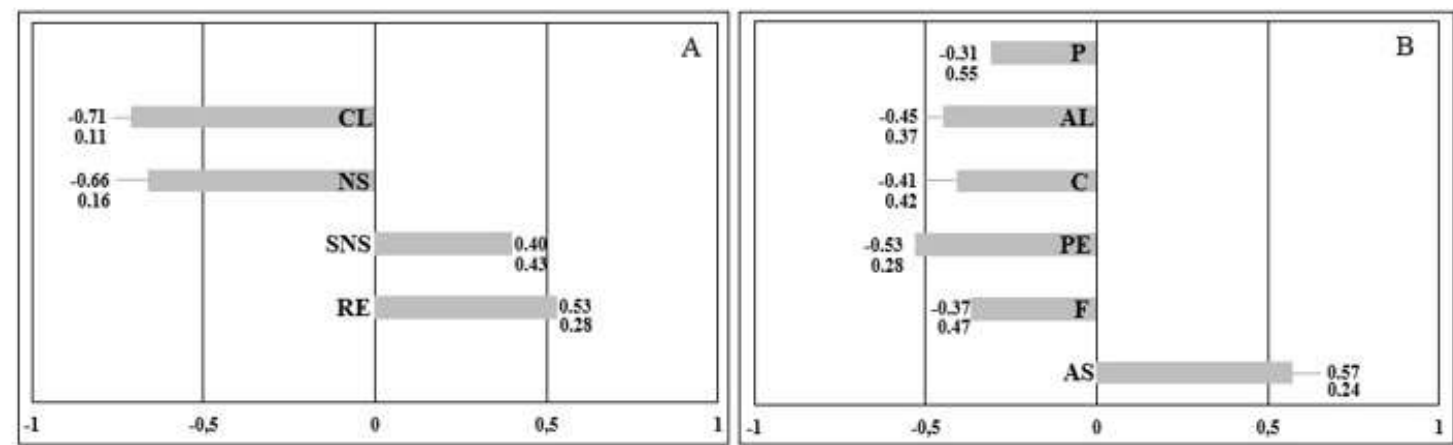

Figure 5. Pearson correlation coefficient between soaking times in anode water and physiological quality variables (A) and between soaking time in anode water and incidence of fungi (B). Seedlings with expanded cotyledonary leaves (CL); Normal seedlings (NS); Strong normal seedlings (SNS); Root emergence (RE); Phoma spp. (P); Alternaria spp. (AL); Cladosporium spp. (C); Penicillium spp. (PE); Fusarium spp. (F); and Aspergillus spp. (AS).

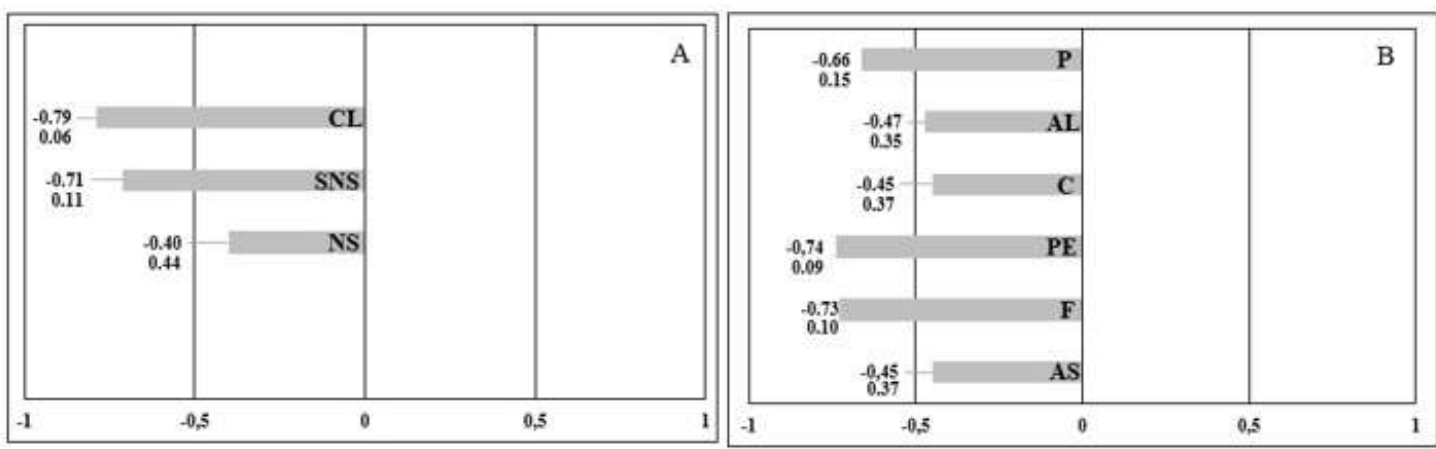

Figure 6. Pearson correlation coefficient between soaking times in cathode water and physiological quality variables $(A)$ and between soaking time in cathode water and incidence of fungi (B). Seedlings with expanded cotyledonary leaves (CL); Normal seedlings (NS); Strong normal seedlings (SNS); Phoma spp. (P); Alternaria spp. (AL); Cladosporium spp. (C); Penicillium spp. (PE); Fusarium spp. (F); and Aspergillus spp. (AS). 
The results of Pearson correlation between soaking time in anode water and incidence of fungi (Figure 5 B) show that the longer the treatment time, the lower the incidence of the fungi, except for Aspergillus spp., confirming the antifungal effect of the anode water and its benefits for the health of coffee seeds.

The results of Pearson correlation between soaking time in cathode water and physiological tests (Figure 6A) and between soaking time in cathode water and incidence of fungi (Figure 6B) show that the longer the seed exposure time, the lower the results of the physiological tests and the lower the incidence of fungi.

In general, the use of anode water or cathode water on seeds may be a beneficial tool, especially from the seed health perspective, since the number of fungi decreases after soaking, especially in seeds that have slow germination, as is the case of Coffea species, in which control of proliferation of fungi is of utmost importance during germination and emergence in forming seedlings for planting. However, more extensive studies must be performed to improve understanding of the activity of these hydrolyzed waters on seed tissues and the ideal soaking time for each species.

\section{CONCLUSIONS}

Soaking in hydrolyzed water, cathode water or anode water, up to 24 hours leads to improvement in the physiological quality of coffee seeds.

Anode water has a beneficial effect on the health of coffee seeds, reducing the incidence of Fusarium spp., Penicillium spp., Cladosporium spp., and Alternaria spp. after one hour of soaking and of Aspergillus spp. after six hours.

Soaking in cathode water for a period of one hour decreases the number of fungi of Aspergillus spp., Fusarium spp., Cladosporium spp., and Alternaria spp., and of Penicillium spp. in soaking for six hours.

Hydrolyzed water, cathode and anode, do not lead to reduction in the incidence of Phoma spp. in coffee seeds.

\section{REFERENCES}

ABREU, G.F.; ROSA, S.D.V.F.; MALTA, M.R.; CLEMENTE, A.C.S.; VILELA, A.L.; RUCYAN, W.P. Antioxidant enzymes preserving coffee quality in refrigerate environment. Biotecnologia Vegetal, v.18, p.151-159, 2018. http://www.alice.cnptia.embrapa.br/alice/ handle/doc/1108915

ATANASOV, A.; KARADZHOV, S.; IVANOVA, E.; MOSIN, O.V.; IGNATOV, I. Study of the effects of electrochemical aqueous sodium chloride solution (anolite) on the virus of classical swine fever virus. Mathematical models of anolyte and catolyte as types of water. Journal of Medicine, Physiology and Biophysics, v.4, p.1-26, 2014. https://core.ac.uk/reader/234697340

BERJAK, P.; SERSHEN, B.V.; PAMMENTER, N.W. Cathodic amelioration of the adverse effects of oxidative stress accompanying procedures necessary for cryopreservation of embryonic axes of recalcitrant-seeded species. Seed Science Research, v.21, n.3, p.187-203, 2011. https://doi.org/10.1017/S0960258511000110

BRASIL. Ministério da Agricultura, Pecuária e Abastecimento. Regras para análise de sementes. Ministério da Agricultura, Pecuária e Abastecimento. Secretaria de Defesa Agropecuária. Brasília: MAPA/ACS, 2009. 399p. https://www.gov.br/agricultura/pt-br/ assuntos/insumos-agropecuarios/arquivos-publicacoes-insumos/2946_regras_analise_sementes.pdf

CLEMENTE, A.C.S.; CARVALHO, M.L.M.; GUIMARÃES, R.M.; ZEVIANI, W.M. Preparo das sementes de café para a avaliação da viabilidade pelo teste de tetrazólio. Revista Brasileira de Sementes, v.33, n.1, p.38-44, 2011. http://dx.doi.org/10.1590/S010131222011000100004

COELHO, S.V.B.; ROSA, S.D.V.F.; CLEMENTE, A.C.S.; PEREIRA, C.C.; FIGUEIREDO, M.A.; REIS, L.V. Tolerance of Coffea arabica L. seeds to sub zero temperatures. Ciência e Agrotecnologia, v.41, p.312-321, 2017. http://dx.doi.org/10.1590/1413-70542017413035216

CONAB. Companhia Nacional de Abastecimento. Acompanhamento de safra brasileira - café: primeiro levantamento, jan. 2019 safra 2019. Brasília: Companhia Nacional de Abastecimento, 2019. Available at: <https://www.conab.gov.br/info-agro/safras/cafe/ boletim-da-safra-de-cafe>. Accessed on March 25, 2019.

FERREIRA D.F. Sisvar: a guide for its bootstrap procedures in multiple comparisons. Ciência e Agrotecnologia, v.38, n.2, p.109-112, 2014. http://dx.doi.org/10.1590/S1413-70542014000200001 
FRANCESCHELLI, S.; GATTA, D.M.P.; PESCE, M.; FERRONE, A.; PATRUNO, A.; LUTIIS, M.A.; GRILLI., A.; FELACO, M.; CROCE, F.; SPERANZA, L. New approach in translational medicine: effects of electrolyzed reduced water (ERW) on NF-KB/Inos pathway in U937 cell line under altered redox state. International Journal of Molecular Sciences, v.17, n.9, 2016. https://www.ncbi.nlm.nih. gov/pmc/articles/PMC5037740/

GLUHCHEV, G.; IGNATOV, I.; KARADZHOV, S.; MILOSHEV, G.; IVANOV, N.; MOSIN, O. Studying the virucidal and biocidal effects of electrochemically activated anolyte and catholyte types of water on classical swine fever virus (CSF) and bacterium E. coli DH5. Journal of Medicine, Physiology and Biophysics, v.13, 2015. https://pdfs.semanticscholar.org/aebf/35e0328e4fedb815bb84f0e04bf5ac036233.pdf

HANAOKA, K. Antioxidant effects of reduced water produced by electrolysis of sodium chloride solutions. Journal of Applied Electrochemistry, v.31, n.12, p.1307-1313, 2001. https://link.springer.com/article/10.1023/A:1013825009701

HANAOKA, K.; SUN, D.; LAWRENCE, R.; KAMITANI, Y.; FERNANDES, L. The mechanism of enhanced antioxidant effects against superoxide anion radicals of reduced water produced by electrolysis. Biophysical Chemistry, v.107, n.1, p.71-82, 2004. 10.1016 / j.bpc.2003.08.007

HIRAOKA, A.; TAKEMOTO, M.; SUZUKI, T.; SHINOHARA, A.; CHIBA, M.; SHIRAO, M.; YOSHIMURA, Y. Studies on the properties and real existence of aqueous solution systems that are assumed to have antioxidant activities by the action of 'active hydrogen'. Journal of Health Science, v.50, n.5, p.456-465, 2004. https://doi.org/10.1248/jhs.50.456

ICO. International Coffee Organization. Produção total dos países exportadores de café. Available at: <https://www.cecafe.com.br/ dados-estatisticos/producao-mundial/>. Accessed on March 25, 2019.

NAIDOO, C.; BERJAK, P.; PAMMENTER, N.W.; VARGHESE, B. The role of reactive oxygen species and antioxidants during precooling stages of axis cryopreservation in recalcitrant Trichilia dregeana. Botany, v.94, n.5, p.391-403, 2016. DOI: 10.1139 / cjb-2015-0248

MARCOS-FILHO, J. Fisiologia de sementes de plantas cultivadas. 2. ed. Londrina: ABRATES, 2015. 660p.

PAMMENTER, N.W.; BERJAK, P. Physiology of desiccation-sensitive (recalcitrant) seeds and the implications for cryopreservation. International Journal Plant Science, v.175, n.1, p.21-28, 2014. DOI: 10.1086 / 673302

R Core Team R: a language and environment for statistical computing. $R$ Foundation for Statistical Computing, Vienna, Austria. https://www.R-project.org/.(2018).

SHARMA, P.; JHA, A.B.; DUBEY, R.S.; PESSARAKLI, M. Reactive oxygen species, oxidative damage and antioxidative defense mechanism in plants under stressful conditions. Journal of Botany, v.26, n.1, p.1-26, 2012. http://dx.doi.org/10.1155/2012/217037

VIDIGAL, D.S.; DIAS, D.C.F.S.; VON PINHO, E.V.R.; DIAS, L.A.S. Alterações fisiológicas e enzimáticas durante a maturação de sementes de pimenta (Capsicum annuum L.). Revista Brasileira de Sementes, v.31, n.2, p.129-136, 2009. http://dx.doi.org/10.1590/S010131222009000200015 use, distribution, and reproduction in any medium, provided the original work is properly cited. 